\title{
Diet Chocolates and Replacement of Cocoa Powder with Jackfruit Seed Powder*
}

\author{
Akshaya Ravindran, Maya Raman, Ninisha Babu, Ammu Dinakaran*, T. V. Sankar, \\ T. K. Srinivasa Gopal \\ Center of Excellence in Food Processing Technology Kerala University of Fisheries and Ocean Studies, Madavana P.O., India \\ Email: ^ammu.dinakaran@gmail.com
}

How to cite this paper: Ravindran, A., Raman, M., Babu, N., Dinakaran, A., Sankar, T.V. and Gopal, T.K.S. (2020) Diet Chocolates and Replacement of Cocoa Powder with Jackfruit Seed Powder. Food and Nutrition Sciences, 11, 220-233. https://doi.org/10.4236/fns.2020.113017

Received: February 11, 2020

Accepted: March 16 ', 2020

Published: March 19, 2020

Copyright (c) 2020 by author(s) and Scientific Research Publishing Inc. This work is licensed under the Creative Commons Attribution International License (CC BY 4.0).

http://creativecommons.org/licenses/by/4.0/

\begin{abstract}
Chocolate is a very popular food product that is relished by millions of people for its unique, rich and sweet taste. The health benefits of chocolate are immense which is attributed to its high polyphenolic content. In the current study, the diet chocolates using natural and artificial sweeteners were developed. Also, the jackfruit seed powder after fermentation (anaerobic and aerobic) was used to replace cocoa powder by $10 \%$. The physiochemical and glycemic index of the chocolates were analyzed. The physiochemical analysis of the chocolates indicated that substitution of jackfruit seed powder did not alter significantly the proximate composition. It was found out that the glycemic index and glycemic load of the chocolates were significantly lower than commercial milk chocolate, which makes it a suitable food product for diabetic and other groups. The samples were packed in pouches made of metallised polyester films laminated with polyethylene for storage studies. Instrumental textural studies were in concordance with sensory observation, indicating that the product remained stable for 3 months at room temperature $\left(26^{\circ} \mathrm{C} \pm 2^{\circ} \mathrm{C}\right)$. The color of the product remained similar throughout the storage period indicating stable structural and surface characteristics. Hence, the chocolates developed using natural and artificial sweeteners have low GI and will minimize the risk of several chronic diseases including diabetes and the use of jackfruit seed powder as a substitute for cocoa powder has not altered any of the characteristic features of chocolate.
\end{abstract}

\section{Keywords}

Diet Chocolate, Stevia, Sucralose, Jackfruit Seed Powder, Glycemic Index

\section{Introduction}

Chocolate is highly complex and is known as indulgent confection. It is a versa-

*All authors contributed equally. 
tile food that can give completely different taste and textural sensations. It is generally consumed for its delicious taste, characteristic texture, softening nature in the mouth, unusual aroma and a slightly bittersweet taste. Chocolates are rich in fat (saturated fat) and sugar. Cocoa is the principle component of chocolate and is rich in polyphenolic compounds (flavan-3-ols such as, catechins, epicatechins and procyanidins), which contribute to health benefits. These also are rich in minerals, flavonols, biogenic amines, methylxanthines (theobromine), aliphatic alcohols and cannabinoid-like fatty acids [1] [2]. Studies imply that high intake of dietary flavanoids contributes to reduced risk of coronary heart diseases and other related disorders [3] [4] [5].

Chocolates are also consumed for its healing properties [6]. The medicinal application of chocolate also includes drug-delivery system [6] [7]. Dark chocolates were consistently associated with better physical health, body composition and are recommended to have short-term benefits on reducing blood pressure and serum cholesterol, improving insulin sensitivity and lower the risk of cardiovascular disease and diabetes [8] [9] [10] [11] [12] [13]. It is also considered as mood enhancer and improves cognitive performance [14].

The chocolate is also considered as complete food and its chief ingredients include cocoa powder (containing cocoa liquor), cocoa butter and sugar. Milk powder, sweeteners and other ingredients such as emulsifier (lecithin) are also added to it to improve nutritional and textural characteristics [15]. These contribute to the chief components such as fat (oleic, palmitic and stearic acid), antioxidants (flavonoids, epicatechin, catechin and procyanidins), nitrogenous compounds (proteins, methylxanthines-theobromine and caffeine) and minerals (potassium, phosphorus, copper, iron, zinc, magnesium), which modulate the health conditions.

The current study investigates the effect of natural and artificial sweetener on chocolate physico-chemical characteristics. It also investigates the feasibility for the utilization of jackfruit seed powder as a replacement for cocoa powder and its effect on the palatability and physiochemical characteristics. The effect of sweeteners and jackfruit seed substitution on the glycemic index is also investigated in the present study.

\section{Materials and Methods}

\subsection{Materials}

Commercial cocoa powder, milk powder and emulsifier purchased from a local supermarket (Cochin, Kerala, India) were used for the chocolate production. The chokita (cocoa butter equivalent) was purchased from Aak Kamani, Mumbai, India. The sweeteners, stevia (Sugar Free, Green, Zydus wellness, India) and sucralose (Sugar Free, Natura, Zydus wellness, India) were purchased online from Amazon, India. Other analytical grade chemicals used in the experiments were obtained from HiMedia ${ }^{\oplus}$ and Sigma-Aldrich ${ }^{\oplus}$ (Cochin, Kerala, India). Water used in the experiments was deionized unless specified otherwise. 


\subsection{Jackfruit Seed Fermentation}

Jackfruit seed powder was produced after fermentation of whole jackfruit. The seeds were placed in mud pots with jackfruit pulp and perianth and allowed to ferment anaerobically for 8 days in the presence of yeast $(0.5 \%)$ and sugar (15\%). The boxes were tightly closed to promote anaerobic fermentation. After anaerobic fermentation, the boxes were opened as shown in Figure 1(a), mixed thoroughly daily and subjected to aerobic fermentation for 8 days to promote oxidation (Figure 1(b)). The seeds were collected and spermoderm were removed. The cleaned seeds were dried using hot air drier $\left(183^{\circ} \mathrm{C} / 48 \mathrm{~h}\right.$, Excalibur, US); roasted and powdered and yield was calculated [16] (Figure 1).

\subsection{Preparation of Chocolates}

Chocolate base, chokita was melted until it becomes free flowing liquid $\left(50^{\circ} \mathrm{C}\right.$.). To this, cocoa powder, milk powder, lecithin and sweetener were added mixed thoroughly and ground using mechanical grinder to ensure uniform mixing. These were then poured in a polycarbonate set mould and refrigerated for 15 min till it solidified (Figure 2). In jackfruit seed powder incorporated chocolates, the cocoa powder was replaced with $10 \%$ jackfruit seed powder (Table 1).

\subsection{Physio-Chemical Characterization}

The moisture (method 925.10), ash (method 923.03), protein $(\mathrm{N} \times 6.25)(960.52)$ (KEL PLUS digestion (KES $06 \mathrm{R}$ ) and distillation systems (DISTYL EM S), M/s

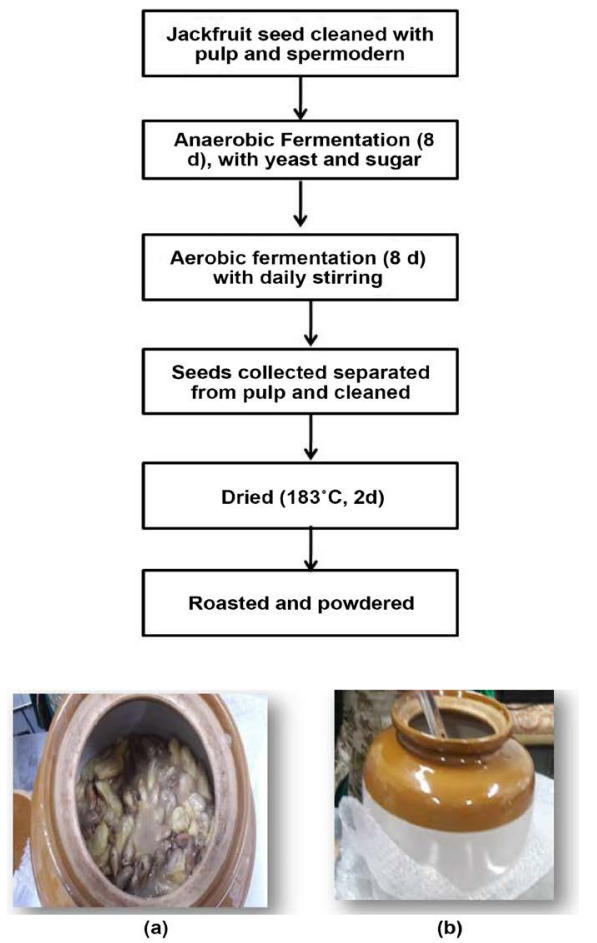

Figure 1. Flow chart showing the preparation of jackfruit seed powder. Figures (a) After anaerobic fermentation for 8 days, (b) aerobic fermentation (8 days). 


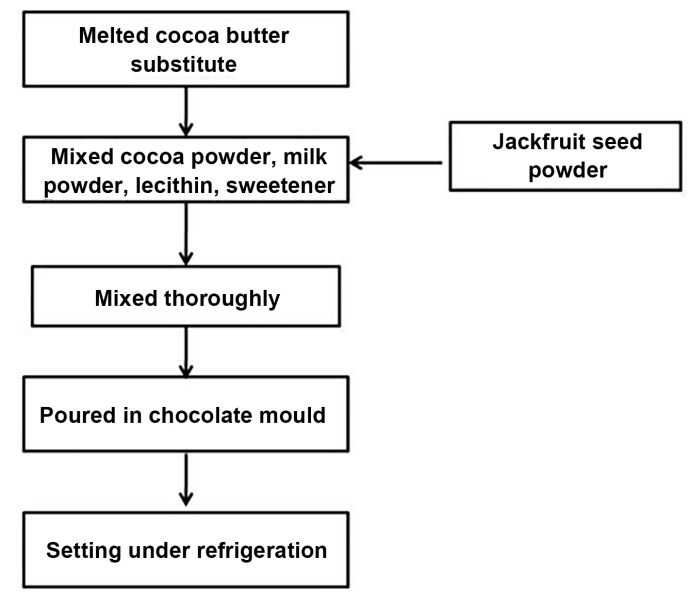

Figure 2. Flow chart showing the protocol for the preparation of chocolate.

Table 1. Composition of chocolates.

\begin{tabular}{|c|c|c|c|c|c|c|}
\hline \multirow[t]{2}{*}{ Composition } & \multicolumn{3}{|c|}{ Diet chocolate (100 g) } & \multicolumn{3}{|c|}{ Jackfruit seed powder (JF) incorporated chocolate $(100 \mathrm{~g})$} \\
\hline & Control & Sucralose-C & Stevia-C & JF-Control & JF-Sucralose & JF-Stevia \\
\hline Cocoa powder $(\mathrm{g})$ & 16 & 16 & 16 & 12 & 14 & 14 \\
\hline Jackfruit seed powder (g) & 0 & 0 & 0 & 4 & 2 & 2 \\
\hline Cocoa butter substitute (g) & 32 & 39 & 39 & 32 & 39 & 39 \\
\hline Milk powder (g) & 27 & 33 & 33 & 27 & 33 & 33 \\
\hline Emulsifier (g) & 7 & 11 & 11 & 7 & 11 & 11 \\
\hline Sugar (g) & 18 & 0 & 0 & 18 & 0 & 0 \\
\hline Sucralose (g) & 0 & 0.085 & 0 & 0 & 0.085 & 0 \\
\hline Stevia (g) & 0 & 0 & 1 & 0 & 0 & 1 \\
\hline
\end{tabular}

Pelican Equipments, Tamil Nadu, India) and lipid contents (2003.05) (SOCS PLUS SCS2 R, M/s Pelican Equipments, Tamil Nadu, India) were determined according to AOAC (2005). The total dietary fiber (TDF) was determined using FIBRA PLUS FES 02 E (M/s Pelican Equipments, Tamil Nadu, India). The caloric value of the chocolates was calculated using the Atwater conversion factors, where by the major biochemical constituents were converted into calorific values using standard calorific equivalents $(5.65,9.45$, and 4.20 for proteins, lipids, and carbohydrates, respectively) [17] [18].

$$
\begin{gathered}
\text { Total carbohydrate }(\mathrm{g} / 100 \mathrm{~g})=100-(\text { moisture }+ \text { protein }+ \text { lipid }+ \text { ash }) \\
\text { Calorific value }(\mathrm{kcal} / \mathrm{g})=(4.20 \times P+9.45 \times L+4.20 \times C) / 100
\end{gathered}
$$

where $P=$ protein content, $L=$ crude lipid content, $C=$ carbohydrate content

The reducing and non-reducing sugars were determined by Lane and Eynon method [19].

\subsection{Estimation of Glycemic Index of Chocolates}

The modified procedure of Giri et al. [20] was used to estimate glycemic index 
(GI) of chocolates. The percent available starch and starch hydrolysis index 90 (HI 90) was calculated as per the formula given by Goni et al. [21] and Holm et al. [22].

The chocolate samples $(250 \mathrm{mg}$ ) were homogenized with $5 \mathrm{ml}$ distilled water (DW) and then made up to $10 \mathrm{ml}$ with DW. It was then treated with $200 \mu \mathrm{l}$ $\alpha$-amylase (heat stable) enzyme (M/s Sigma, Cochin, India) for $15 \mathrm{~min}$ in a boiling water bath with mixing after every $5 \mathrm{~min}$. The suspension was cooled and diluted to a final volume of $25 \mathrm{ml}$ with DW. The clear solution from top (1 ml) was incubated with $2 \mathrm{ml}$ of sodium phosphate buffer $(\mathrm{pH} 4.75)$ and $1 \mathrm{ml}$ of amyloglucosidase solution (5 mg amyloglucosidase dissolved in $25 \mathrm{ml}$ of same buffer) (M/s Sigma, Cochin, India) at $60^{\circ} \mathrm{C}$ for $30 \mathrm{~min}$ with gentle mixing every $5 \mathrm{~min}$. It was then diluted to $10 \mathrm{ml}$ with $\mathrm{DW}$. Glucose was estimated by using GOD-POD kit and the percentage available starch was estimated using the equation:

Percent available starch $=(\mu$ g glucose $\times 25 \times 0.9) /$ sample wt. $(\mathrm{mg}$, dry weight basis)

For the estimation of hydrolysis index (HI90), chocolate $(1 \mathrm{~g})$ was homogenized and suspended in $50 \mathrm{ml}$ of $0.1 \mathrm{M}$ phosphate buffer ( $\mathrm{pH}$ 6.9); and then incubated with $5 \mathrm{ml}$ of same buffer containing $500 \mathrm{mg}$ pancreatin (M/s Sigma, Cochin, India) was added and the mixture was incubated at $37^{\circ} \mathrm{C}$ with gentle mixing for $90 \mathrm{~min}$. Clear sample solution $(0.1 \mathrm{ml})$ was drawn and analyzed for maltose using the DNSA method [21]. Results were expressed as mg maltose released after $90 \mathrm{~min}$ of hydrolysis of $1 \mathrm{~g}$ sample (dry weight). Using these values and percent available starch, hydrolysis index was calculated using the formula,

$$
\text { HI90 }=100 \times 0.9 \times \mathrm{mg} \text { maltose } / \mathrm{mg} \text { starch }
$$

Using the values of percent available starch and HI 90, GI was calculated using the formula as given by Goni et al. [21].

$$
\mathrm{GI}=39.21+0.803 \times \mathrm{HI} 90
$$

\subsection{Storage Studies}

The products were packed in 50 gauge metallised polyester laminated with 220 gauge Polyethylene packets to analyze the shelf life of the product. The changes that occurred in the product during the period of storage $(0,30,60,90$ and 120 days) were analyzed based on melting characteristics, Texture profile analysis, color analysis and sensory evaluation.

\subsubsection{Texture Profile Analysis}

The chocolate samples were analyzed for texture profile analysis using a Shimadzu Texture Analyzer (EZ LX HS). Trapezium Software was used to determine the parameters like Hardness 1, Hardness 2, Cohessiveness, Springiness and Chewiness. The Texture analyzer is equipped with a load cell of $100 \mathrm{~N}$. Cylindrical probe of $35 \mathrm{~mm}$ diameter was used at a test speed of $1 \mathrm{~mm} / \mathrm{s}$ and trigger force: $9.8 \mathrm{~N}$. The samples were Compressed to an extent of $48 \%$. All values are 
given as an average of three measurements and the total texture change were evaluated [23].

\subsubsection{Sensory Evaluation}

The sensory evaluation of chocolate samples was carried out for consumer acceptance and preference by 10-panel members, using a ten-point Hedonic Scale ( 1 and 10, representing extreme dislike and extreme like, respectively). Coded samples of the same size were served to participants in identical containers.

\subsubsection{Color Analysis}

The CIE Lab coordinate of the chocolate samples were determined using Color Flex EZ (Hunterlab, USA) reporting lightness $\left(\mathrm{L}^{*}\right)$, redness $\left(\mathrm{a}^{\star}\right)$, and yellowness $\left(b^{\star}\right)$. Measurements were done at nine different points and mean values were reported for each sample.

\subsubsection{Whiteness Index}

Whiteness Index (WI) was calculated according to [24] [25].

$$
W I=100-\left[\left(100-L^{*}\right)^{2}+\left(a^{* 2}+b^{* 2}\right)\right]^{1 / 2}
$$

where, $L^{\star}, a^{\star}$ and $b^{\star}$ refer to the CIE Lab coordinates determined using Color Flex EZ. The whiteness index is useful information about changes in texture properties of samples [26] [27] [28]. The whiteness index measures the kinetics of color changes on the surface of chocolate caused by fat migration from the interior, which leads to certain changes in the structure and texture of the product [29] [30] [31].

\subsection{Statistics}

All results are expressed given as means and standard deviation. Analysis of variance was conducted using one-way ANOVA and Tukey test by pair-wise analysis with significance defined at $p<0.05$.

\section{Results and Discussion}

\subsection{Physiochemcial Characterization of Chocolates}

The physio-chemical composition of chocolates is given in Table 2. The results showed that moisture content ranged between 2.7 and $4.1 \mathrm{~g} \%$, with control (sugar) showing the lowest moisture content, which was in accordance with earlier reports [32]. The chemical nature and the initial moisture content of the alternative sweeteners and other ingredients influence the ultimate moisture content of the chocolate; thus, affecting its sensory properties and flow characteristics of the chocolate [32]. The mineral contents ranged between 2.6 and $4.4 \mathrm{~g} \%$, with lowest being in jackfruit control. The fat content in the chocolates ranged between 55.0 and $58.9 \mathrm{~g} \%$. The carbohydrate content ranged between 22.5 and $34.5 \mathrm{~g} \%$, with highest being in jackfruit control. 
Table 2. Physicochemical composition of chocolates.

\begin{tabular}{ccccccc}
\hline & Control & Stevia-C & Sucralose-C & JF-control & JF-Stevia & JF-Sucralose \\
\hline Moisture (g\%) & $2.7 \pm 0.1$ & $3.9 \pm 0.7$ & $4.0 \pm 0.4$ & $3.9 \pm 0.7$ & $4.1 \pm 0.5$ & $3.9 \pm 0.7$ \\
Ash (g\%) & $4.0 \pm 0.1$ & $4.4 \pm 0.2$ & $4.3 \pm 0.0$ & $2.6 \pm 0.01$ & $4.4 \pm 0.1$ & $4.2 \pm 0.0$ \\
Fat (g\%) & $55.0 \pm 0.03$ & $56.0 \pm 0.6$ & $58.9 \pm 0.02$ & $51.6 \pm 0.01$ & $57.3 \pm 0.1$ & $58.7 \pm 0.04$ \\
Protein (g\%) & $7.9 \pm 0.2$ & $10.03 \pm 0.3$ & $10.3 \pm 0.04$ & $7.4 \pm 0.1$ & $8.6 \pm 1.3$ & $10.3 \pm 0.3$ \\
Carbohydrate (g\%) & $30.4 \pm 0.1$ & $25.7 \pm 0.5$ & $22.5 \pm 0.3$ & $34.5 \pm 0.1$ & $25.4 \pm 0.1$ & $22.9 \pm 0.2$ \\
Fiber (g\%) & $6.8 \pm 0.2$ & $7.1 \pm 0.2$ & $7.4 \pm 0.2$ & $6.5 \pm 0.2$ & $7.1 \pm 0.02$ & $7.3 \pm 0.1$ \\
Reducing sugar (g\%) & $6.0 \pm 0$ & $16.6 \pm 0$ & $14.7 \pm 0$ & $5.7 \pm 0$ & $8.4 \pm 0$ & $5.8 \pm 0$ \\
Non-reducing sugar (g\%) & $5.2 \pm 0$ & $1.2 \pm 0$ & $2.0 \pm 0$ & $5.0 \pm 0$ & $8.3 \pm 0$ & $5.2 \pm 0$ \\
Total sugar (g\%) & $11.3 \pm 0$ & $17.8 \pm 0$ & $16.7 \pm 0$ & $10.7 \pm 0$ & $16.7 \pm 0$ & $11.4 \pm 0$ \\
Calories (kcal/g) & 6.9 & 6.9 & 7.1 & 6.7 & 7.0 & 7.1 \\
\hline
\end{tabular}

Stevia-C: Stevia chocolate, Sucralose-C: Sucralose chocolate, JF-Jackfruit.

\subsection{Glycemic Index and Glycemic Load of Chocolates}

The glycemic index and glycemic load for the chocolates are shown in Table 3. The earlier reports indicate that foods with Glycemic Index (GI) less than 55 are classified as low GI, 56 - 69 as medium GI and greater than 70 as high GI [33]. The results clearly show that the chocolates fall under the category of low glycemic Index foods. Low GI diet has therapeutic value in type 1 and type 2 diabetic patients [34]. According to Bjorck and Asp [35] GI has an effect on the nutritional quality of food. Low GI foods are recommended not only for diabetic individuals but also for normal population. The glycemic index for a commercial milk chocolate shows that it comes under high GI and thus is not suitable for diabetic patients.

\subsection{Storage Studies}

\subsubsection{Texture Profile Analysis}

The different parameters in texture profile analysis was evaluated during storage periods $(0,30,60,90$ and 120 days) and the changes in the textural parameters such as Hardness 1, Hardness 2, Cohessiveness, Springiness and chewiness are shown in Figures 3(a)-(e), respectively. The results showed that the chocolate samples with sugar as the sweetener (Control, con and Jackfruit Control, JF C) had high hardness values than other samples. In samples with sucralose and stevia as sweetener (Sucralose Chocolate, Suc C; Stevia chocolate, St C; Jackfruit Sucralose, JF Su; Jackfruit Stevia, JF St) showed less hardness than sugar chocolates. The samples were stored at room temperature which was found to have a profound effect on the hardness 1 and 2 of the sample. The texture profile analysis on the fourth month $\left(120^{\text {th }}\right.$ day) clearly showed a significant decrease in the hardness of the samples. The sensory evaluation results were in accordance with the instrumental results. The cohesiveness, springiness and chewiness values were almost the same for all the samples and did not show any significant 


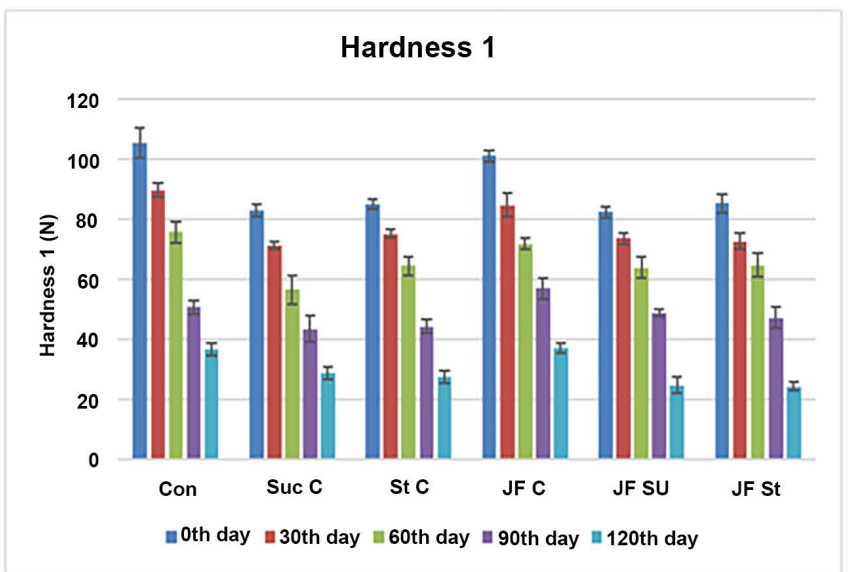

(a)

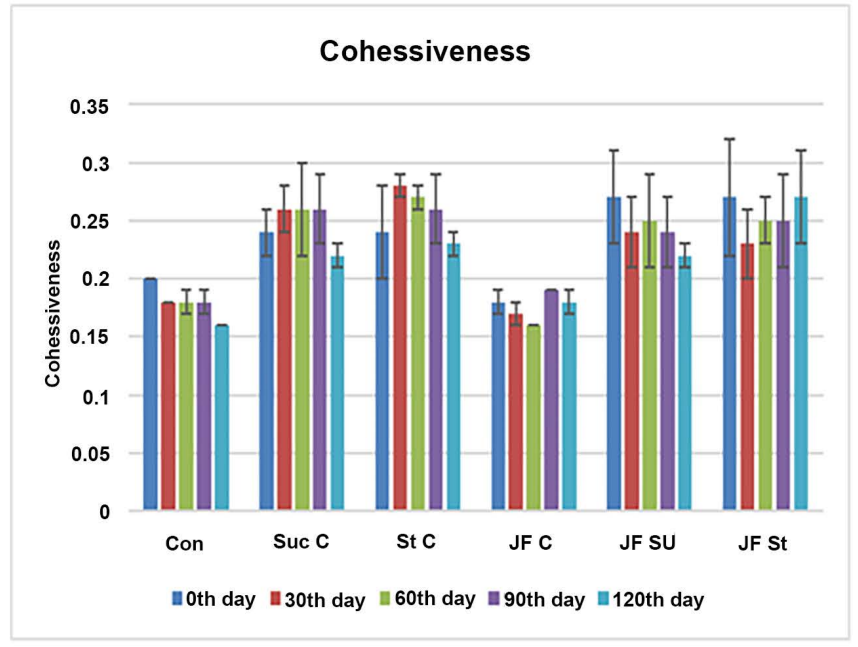

(c)

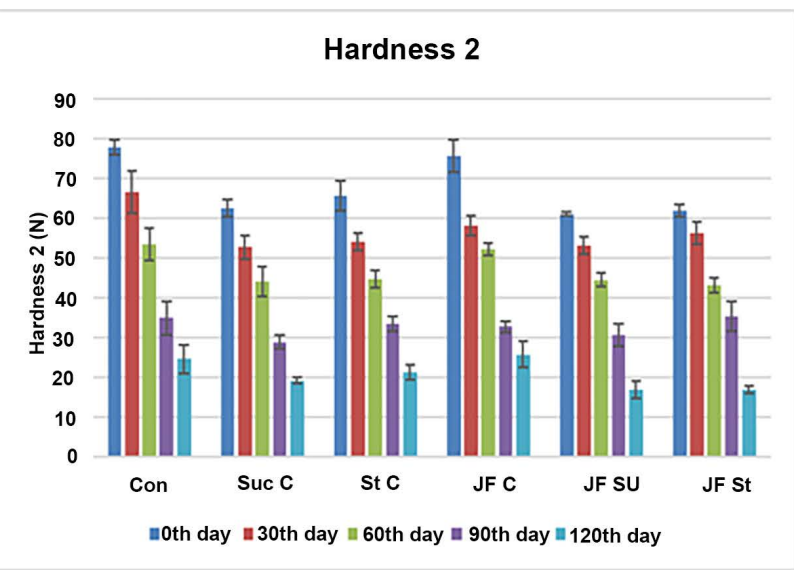

(b)

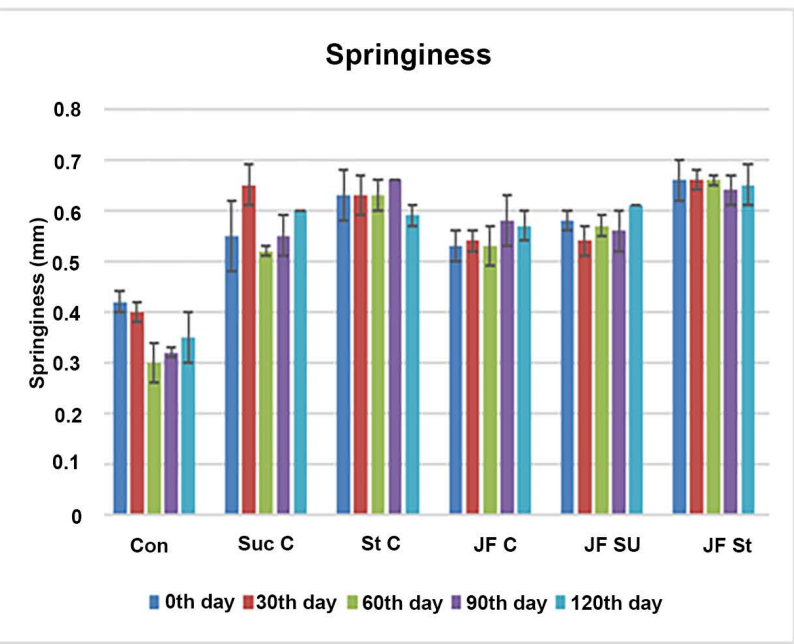

(d)

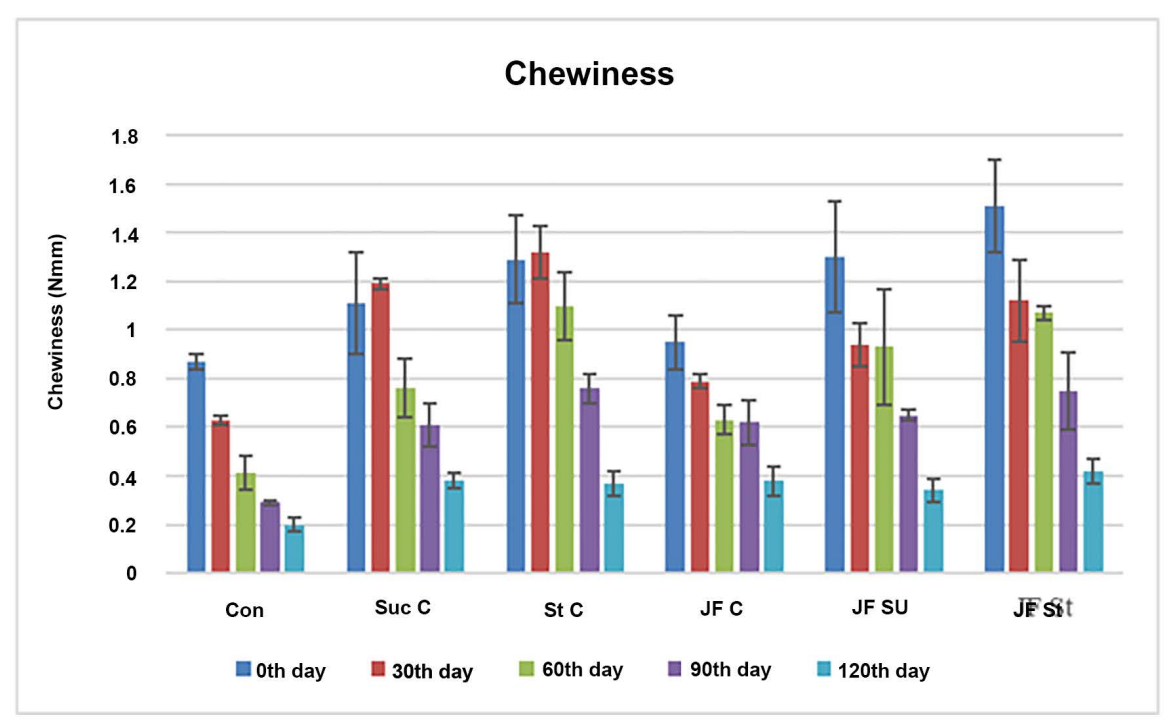

(e)

Figure 3. Texture profile characteristics of the product during the period of storage. (a) Changes in Hardness 1 during storage ( $P$ $<0.05)$; (b) Changes in Hardness 2 during storage $(P<0.05)$; (c) Changes in Cohessiveness during storage; (d) Changes in Springiness during storage. 
Table 3. Glycemic Index and Glycemic Load of chocolates.

\begin{tabular}{lccccc}
\hline & Stevia C & Sucralose C & JF Stevia & JF Sucralose & Commercial chocolate \\
\hline Glycaemic Index (GI) & $42.8 \pm 0.15$ & $42.8 \pm 0.01$ & $44.8 \pm 0$ & $43.6 \pm 0.01$ & $70.8 \pm 1.9$ \\
Glycaemic Load (GL) & $13.2 \pm 0.04$ & $12.0 \pm 0.001$ & $12.3 \pm 0.005$ & $13.7 \pm 0.0002$ & $42.8 \pm 1.18$ \\
\hline
\end{tabular}

Stevia-C: Stevia chocolate, Sucralose-C: Sucralose chocolate, JF-Jackfruit.

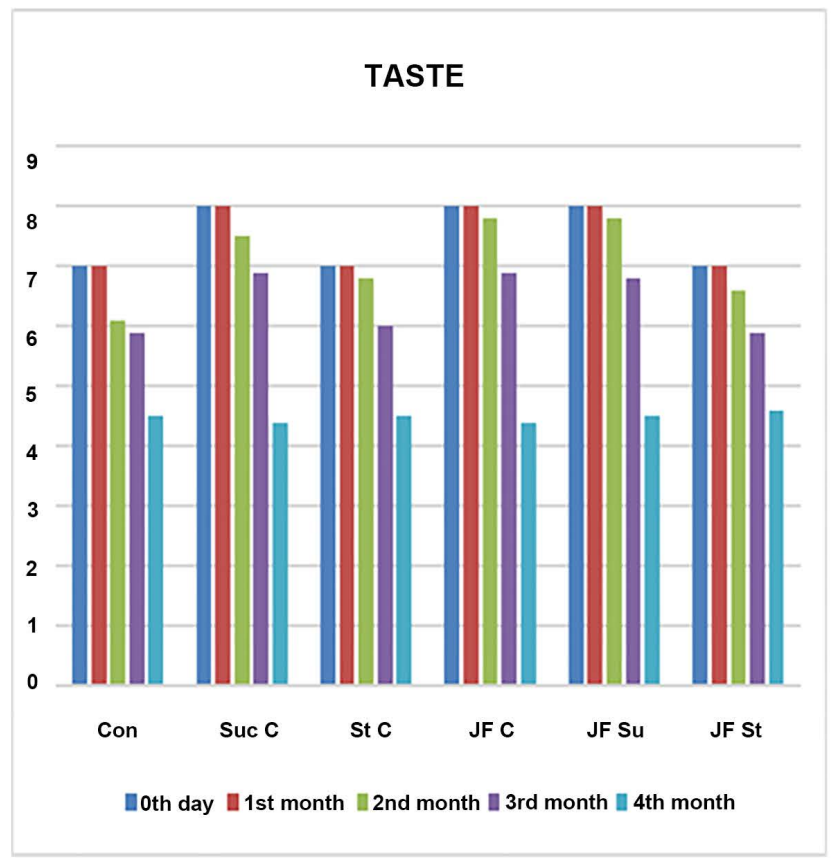

(a)

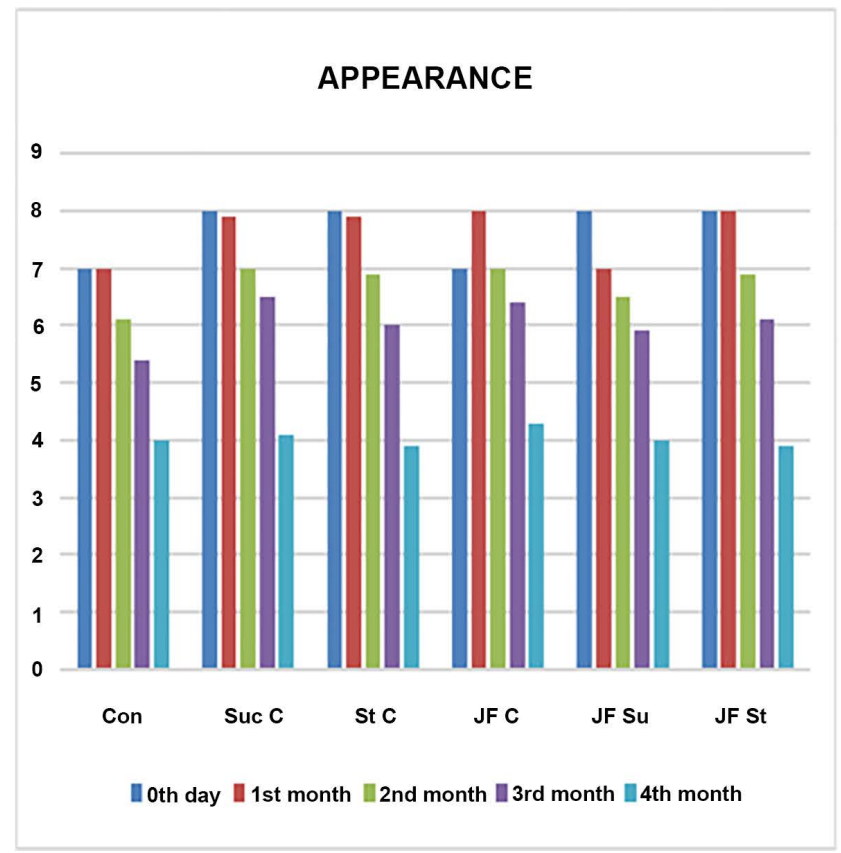

(c)

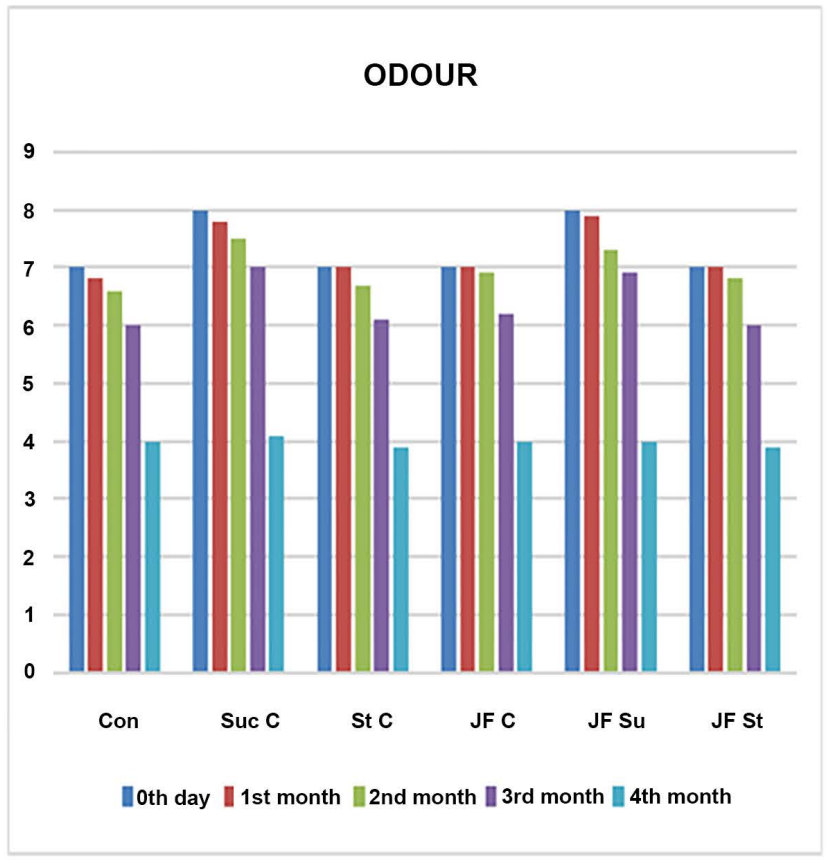

(b)

\section{OVERALL ACCEPTABILITY}

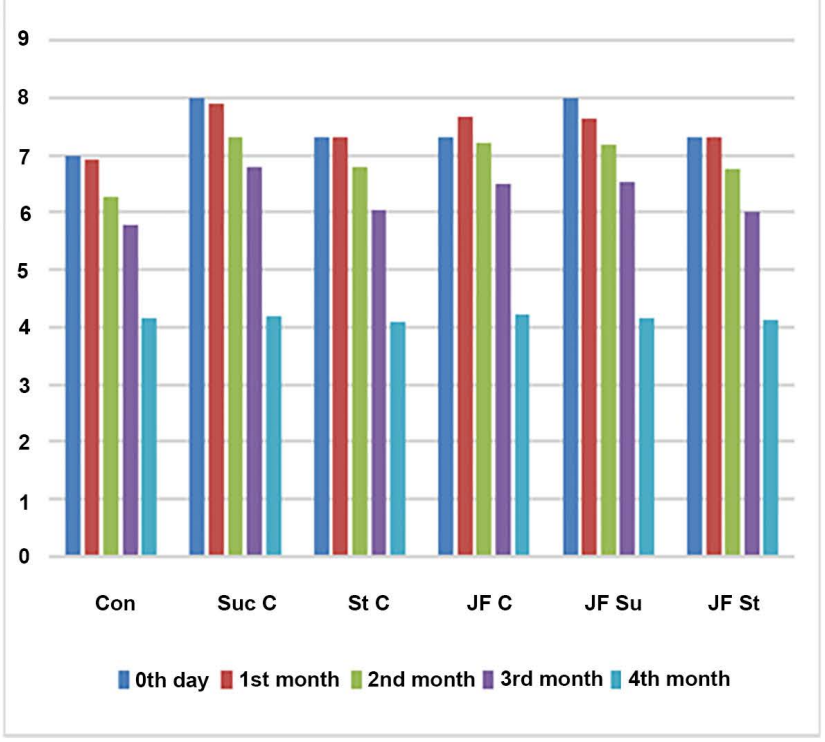

(d)

Figure 4. (a) Sensory score for taste; (b) Sensory Score for Odour; (c) Sensory score for appearance; (d) Overall acceptability. 
Table 4. Color characteristics of chocolates during the period of storage.

\begin{tabular}{|c|c|c|c|c|c|c|}
\hline Days & Control & Stevia-C & Sucralose-C & JF-control & JF-Stevia & JF-Sucralose \\
\hline \multicolumn{7}{|c|}{$L^{*}$} \\
\hline 0 & $31.9 \pm 0.7$ & $30.1 \pm 0.6$ & $30.5 \pm 0.5$ & $31.8 \pm 0.2$ & $30.4 \pm 0.2$ & $30.0 \pm 0.8$ \\
\hline 30 & $33.0 \pm 0.4$ & $30.4 \pm 0.3$ & $28.1 \pm 0.4$ & $31.3 \pm 0.4$ & $30.8 \pm 0.2$ & $29.1 \pm 0.3$ \\
\hline 60 & $31.7 \pm 0.7$ & $30.2 \pm 0.5$ & $30.9 \pm 1.0$ & $32.9 \pm 0.1$ & $28.5 \pm 0.2$ & $30.1 \pm 0.02$ \\
\hline 90 & $31.2 \pm 0.04$ & $30.3 \pm 0.4$ & $30.7 \pm 0.7$ & $31.7 \pm 0.3$ & $29.6 \pm 0.1$ & $30.0 \pm 0.01$ \\
\hline \multicolumn{7}{|c|}{$a^{*}$} \\
\hline 0 & $9.9 \pm 0.2$ & $8.9 \pm 0.2$ & $9.4 \pm 0.3$ & $9.8 \pm 0.2$ & $9.4 \pm 0.2$ & $9.4 \pm 0.1$ \\
\hline 30 & $10.2 \pm 0.01$ & $9.0 \pm 0.1$ & $8.5 \pm 0.2$ & $10.1 \pm 0.1$ & $9.6 \pm 0.1$ & $9.2 \pm 0.3$ \\
\hline 60 & $10.2 \pm 0.8$ & $9.0 \pm 0.3$ & $9.9 \pm 0.1$ & $9.9 \pm 0.2$ & $9.8 \pm 0.4$ & $10.0 \pm 0.2$ \\
\hline 90 & $10.3 \pm 0.4$ & $9.3 \pm 0.3$ & $9.5 \pm 0.6$ & $9.9 \pm 0.1$ & $9.0 \pm 0.04$ & $8.9 \pm 0.01$ \\
\hline \multicolumn{7}{|c|}{$b^{*}$} \\
\hline 0 & $11.5 \pm 0.7$ & $10.3 \pm 0.3$ & $10.9 \pm 0.5$ & $12.3 \pm 0.2$ & $11.2 \pm 0.4$ & $11.2 \pm 0.2$ \\
\hline 30 & $11.8 \pm 0.5$ & $10.6 \pm 0.5$ & $10.3 \pm 0.7$ & $13.0 \pm 0.9$ & $11.8 \pm 0.5$ & $11.8 \pm 1.1$ \\
\hline 60 & $11.7 \pm 0.6$ & $10.1 \pm 0.4$ & $11.1 \pm 0.7$ & $12.3 \pm 0.8$ & $12.9 \pm 0.4$ & $12.8 \pm 0.4$ \\
\hline 90 & $11.7 \pm 0.7$ & $11.2 \pm 0.1$ & $11.8 \pm 0.2$ & $11.3 \pm 0.4$ & $11.0 \pm 0.1$ & $11.9 \pm 0.1$ \\
\hline \multicolumn{7}{|c|}{ Whiteness index } \\
\hline 0 & $30.2 \pm 0.6$ & $28.8 \pm 0.6$ & $29.0 \pm 0.6$ & $30.0 \pm 0.2$ & $28.9 \pm 0.2$ & $28.5 \pm 0.8$ \\
\hline 30 & $31.2 \pm 0.4$ & $29.0 \pm 0.4$ & $26.9 \pm 0.5$ & $29.3 \pm 0.5$ & $29.1 \pm 0.2$ & $27.6 \pm 0.5$ \\
\hline 60 & $29.9 \pm 0.9$ & $29.0 \pm 0.5$ & $29.3 \pm 1.1$ & $31.0 \pm 0.3$ & $26.7 \pm 0.3$ & $28.3 \pm 0.1$ \\
\hline 90 & $29.4 \pm 0.1$ & $28.8 \pm 0.4$ & $29.1 \pm 0.8$ & $30.1 \pm 0.2$ & $28.2 \pm 0.9$ & $28.4 \pm 0.0$ \\
\hline
\end{tabular}

Stevia-C: Stevia chocolate, Sucralose-C: Sucralose chocolate, JF-Jackfruit.

variation during the period of storage. The results also show that $10 \%$ replacement of cocoa powder with jackfruit seed powder did not make significant characteristic changes in the product.

\subsubsection{Sensory Evaluation}

The results of sensory evaluation carried out by the sensory panel with respect to the sensory parameters like taste, odour, appearance and overall acceptance are shown in Figures 4(a)-(d) respectively. The sensory score is below 5 for all the samples on the $4^{\text {th }}$ month. For the first three months the products were well accepted by the sensory panel. There was no fat bloom or fungal growth during the first three months of storage at room temperature $\left(26^{\circ} \mathrm{C} \pm 2^{\circ} \mathrm{C}\right)$. The results clearly show that the products had a good acceptance.

\subsubsection{Color Characteristics and Whiteness Index}

The colour values for the chocolates packed and stored in 50 gauge metalized polyester films laminated with 220 gauge polyethylene is given in Table 4. Analysis of colour values $L^{\star}$ (darkness to lightness), $a^{*}$ (redness to greenness), and $b^{*}$ 
(blueness to yellowness) during the period of storage indicates the physical changes that occur in the product due to bloom formation. The results clearly show that the product had a stable colour with respect to $L^{*}, a^{*}$ and $b^{*}$ values for a period of three months when stored at room temperature. After three months of storage, the product developed fat bloom due to which colour analysis of the samples were not carried out on the $4^{\text {th }}$ month. Whiteness Index (WI) (Table 4) did not show any significant variation among the samples during the entire period of storage possibly indicating no textural changes or changes in surface characteristics [36]. Thus, the product retained a stable structural characteristic during the storage study period.

\section{Conclusion}

The study was aimed for the development of diet chocolates and the utilization of under-utilized jackfruit, a seasonal fruit. Ten percentage replacement of cocoa powder with jackfruit seed powder was a success and did not alter any characteristic features of chocolate. The physiological study clearly showed that the chocolates have a low glycemic index and low glycemic load. Hence, it is a great substitute for chocolates to diabetic patients. The storage study in 50 gauge metallized polyester laminated with 220 gauge polyethylene pouches at room temperature was carried out and monthly analysis was done for four months. After three months the product developed fat bloom and also was not stable on the basis of texture. The results revealed that the diet chocolates have a shelf life of three months and did not undergo any significant changes at room temperature $\left(26^{\circ} \mathrm{C} \pm 2^{\circ} \mathrm{C}\right)$.

\section{Acknowledgement}

The authors sincerely acknowledge Ms. Vynavi, Aakamani, Mumbai for providing Chokita, the cocoa butter substitutes, for conducting the study.

\section{Conflicts of Interest}

The authors declare no conflicts of interest regarding the publication of this paper.

\section{References}

[1] Bruinsma, K. and Taren, L.D. (1999) Chocolate: Food or Drug? Review. Journal of the American Dietetic Association, 99, 1249-1256. https://doi.org/10.1016/S0002-8223(99)00307-7

[2] Knight, I. (2000) Chocolate and Cocoa: Health and Nutrition. Blackwell Science Ltd., Oxford.

[3] Hertog, M.G.L., Kromhout, D., Aravanis, et al. (1995) Flavonoid Intake and Long-Term Risk of Coronary Heart Disease and Cancer in the Seven Countries Study. Archives of Internal Medicine, 155, 381-386. https://doi.org/10.1001/archinte.155.4.381

[4] Geleijnse, J.M., et al. (1999) Tea Flavonoids May Protect against Atherosclerosis: 
The Rotterdam Study. Archives of Internal Medicine, 159, 2170-2174. https://doi.org/10.1001/archinte.159.18.2170

[5] Fuhrman, B. and Aviram, M. (2001) Flavonoids Protect LDL from Oxidation and Attenuate Atherosclerosis. Current Opinion in Lipidology, 12, 41-48. https://doi.org/10.1097/00041433-200102000-00008

[6] Dillinger, T.L., Barriga, P., Escárcega, S., Jimenez, M., Lowe, D.S. and Grivetti, L.E. (2000) Food of the Gods: Cure for Humanity? A Cultural History of the Medicinal and Ritual Use of Chocolate. The Journal of Nutrition, 130, 2057S-2072S. https://doi.org/10.1093/jn/130.8.2057S

[7] Katz, D.L., Doughty, K. and Ali, A. (2011) Cocoa and Chocolate in Human Health and Disease. Antioxidants \& Redox Signaling, 15, 2779-2811.

https://doi.org/10.1089/ars.2010.3697

[8] Buijsse, B., Feskens, E.J., Kok, F.J. and Kromhout, D. (2006) Cocoa Intake, Blood Pressure, and Cardiovascular Mortality: The Zutphen Elderly Study. Archives of Internal Medicine, 166, 411-417. https://doi.org/10.1001/archinte.166.4.411

[9] Grassi, D., Desideri, G., Necozione, S., Lippi, C., Casale, R., Properzi, G., Ferri, C., et al. (2008) Blood Pressure Is Reduced and Insulin Sensitivity Increased in Glucose-Intolerant, Hypertensive Subjects after 15 Days of Consuming High-Polyphenol Dark Chocolate. The Journal of Nutrition, 138, 1671-1676. https://doi.org/10.1093/jn/138.9.1671

[10] Desch, S., Kobler, D., Schmidt, J., Sonnabend, M., Adams, V., Sareban, M., Thiele, H., et al. (2010) Low vs. Higher-Dose Dark Chocolate and Blood Pressure in Cardiovascular High-Risk Patients. American Journal of Hypertension, 23, 694-700. https://doi.org/10.1038/ajh.2010.29

[11] Shrime, M.G., Bauer, S.R., McDonald, A.C., Chowdhury, N.H., Coltart, C.E. and Ding, E.L. (2011) Flavonoid-Rich Cocoa Consumption Affects Multiple Cardiovascular Risk Factors in a Meta-Analysis of Short-Term Studies. The Journal of Nutrition, 141, 1982-1988. https://doi.org/10.3945/jn.111.145482

[12] Buitrago-Lopez, A., Sanderson, J., Johnson, L., Warnakula, S., Wood, A., Di Angelantonio, E. and Franco, O.H. (2011) Chocolate Consumption and Cardiometabolic Disorders: Systematic Review and Meta-Analysis. BMJ, 343, d4488. https://doi.org/10.1136/bmj.d4488

[13] Zhang, Z., Xu, G. and Liu, X. (2013) Chocolate Intake Reduces Risk of Cardiovascular Disease: Evidence from 10 Observational Studies. International Journal of Cardiology, 168, 5448-5450. https://doi.org/10.1016/j.ijcard.2012.12.036

[14] Santiago-Rodríguez, E., Estrada-Zaldívar, B. and Zaldívar-Uribe, E. (2018) Effects of Dark Chocolate Intake on Brain Electrical Oscillations in Healthy People. Foods, 7, 187. https://doi.org/10.3390/foods7110187

[15] Latif, R. (2013) Chocolate/Cocoa and Human Health: A Review. The Netherlands Journal of Medicine, 71, 63-68.

[16] Spada, F.P., Zerbeto, L.M., Ragazi, G.B.C., Gutierrez, E.M.R., Souza, M.C., Parker, J.K. and Canniatti-Brazaca, S.G. (2017) Optimization of Postharvest Conditions to Produce Chocolate Aroma from Jackfruit Seeds. Journal of Agricultural and Food Chemistry, 65, 1196-1208. https://doi.org/10.1021/acs.jafc.6b04836

[17] Atwater, W. (1899) 0. \& Bryant, AP (1900) Rep. (Storrs) Agric. Exp. Sta.

[18] Dare, P.J. and Edwards, D.B. (1975) Seasonal Changes in Flesh Weight and Biochemical Composition of Mussels (Mytilus edulis L.) in the Conwy Estuary, North Wales. Journal of Experimental Marine Biology and Ecology, 18, 89-97. 
https://doi.org/10.1016/0022-0981(75)90066-0

[19] Lane and Eynon Method (1923) Determination of Reducing Sugars by Means of Fehling's Solution with Methylene Blue as Internal Indicator. Journal of the Society of Chemical Industry, 42, 32T-37T.

[20] Giri, S., Banerji, A., Lele, S.S. and Ananthanarayan, L. (2017) Effect of Addition of Enzymatically Modified Guar Gum on Glycemic Index of Selected Indian Traditional Foods (Idli, Chapatti). Bioactive Carbohydrates and Dietary Fibre, 11, 1-8. https://doi.org/10.1016/j.bcdf.2017.05.002

[21] Goñi, I., Garcia-Alonso, A. and Saura-Calixto, F. (1997) A Starch Hydrolysis Procedure to Estimate Glycemic Index. Nutrition Research, 17, 427-437. https://doi.org/10.1016/S0271-5317(97)00010-9

[22] Holm, J., Lundquist, I., Björck, I., Eliasson, A.C. and Asp, N.G. (1988) Degree of Starch Gelatinization, Digestion Rate of Starch in Vitro, and Metabolic Response in Rats. The American Journal of Clinical Nutrition, 47, 1010-1016. https://doi.org/10.1093/ajcn/47.6.1010

[23] Sayed-Ahmad, B., Talou, T., Straumite, E., Sabovics, M., Kruma, Z., Saad, Z., Hijazi, A. and Merah, O. (2018) Evaluation of Nutritional and Technological Attributes of Whole Wheat Based Bread Fortified with Chia Flour. Foods, 7, 135. https://doi.org/10.3390/foods7090135

[24] Robertson, A.R. (1977) The CIE 1976 Color-Difference Formulae. Color Research \& Application, 2, 7-11. https://doi.org/10.1002/j.1520-6378.1977.tb00104.x

[25] Lohman, M.H. and Hartel, R.W. (1994) Effect of Milk Fat Fractions on Fat Bloom in Dark Chocolate. Journal of the American Oil Chemists' Society, 71, 267-276. https://doi.org/10.1007/BF02638052

[26] Petersson, B., Anjou, K. and Sandström, L. (1985) Pulsed NMR Method for Solid Fat Content Determination in Tempering Fats, Part I: Cocoa Butters and Equivalents. Fette, Seifen, Anstrichmittel, 87, 225-230. https://doi.org/10.1002/lipi.19850870603

[27] Torbica, A., Jovanovic, O., Muc, S. and Hartig, E. (2004) Possibility and Importance of Solid Fat Content Determination in Chocolate. "Production and Processing of Oilseeds" Proceedings of the 45 th Oil Industry Conference, Petrovac na moru, 6-11 June 2004, 299-305. (In Serbian)

[28] Torbica, A.M., Pajin, B.S., Omorjan, R.P., Lončarević, I.S. and Tomić, J.M. (2014) Physical Properties of Chocolate with Addition of Cocoa Butter Equivalent of Moderate Hardness. Journal of the American Oil Chemists' Society, 91, 39-48. https://doi.org/10.1007/s11746-013-2357-2

[29] Hartel, R.W. (1999) Chocolate: Fat Bloom during Storage. Manufacturing Confectioner, 79, 89-99.

[30] Briones, V., Aguilera, J.M. and Brown, C. (2006) Effect of Surface Topography on Color and Gloss of Chocolate Samples. Journal of Food Engineering, 77, 776-783.

https://doi.org/10.1016/j.jfoodeng.2005.08.004

[31] Altimiras, P., Pyle, L. and Bouchon, P. (2007) Structure-Fat Migration Relationships during Storage of Cocoa Butter Model Bars: Bloom Development and Possible Mechanisms. Journal of Food Engineering, 80, 600-610. https://doi.org/10.1016/j.jfoodeng.2006.06.022

[32] Saputro, A.D., Van de Walle, D., Aidoo, R.P., Mensah, M.A., Delbaere, C., De Clercq, N., Dewettinck, K., et al. (2017) Quality Attributes of Dark Chocolates Formulated with Palm Sap-Based Sugar as Nutritious and Natural Alternative Sweetener. European Food Research and Technology, 243, 177-191. 
https://doi.org/10.1007/s00217-016-2734-9

[33] Jenkins, D.J., Kendall, C.W., McKeown-Eyssen, G., Josse, R.G., Silverberg, J., Booth, G.L., Banach, M.S., et al. (2008) Effect of a Low-Glycemic Index or a High-Cereal Fiber Diet on Type 2 Diabetes: A Randomized Trial. JAMA, 300, 2742-2753.

https://doi.org/10.1001/jama.2008.808

[34] Miller, J.C. (1994) Importance of Glycemic Index in Diabetes. The American Journal of Clinical Nutrition, 59, 747S-752S. https://doi.org/10.1093/ajcn/59.3.747S

[35] Björck, I. and Asp, N.G. (1994) Controlling the Nutritional Properties of Starch in Foods-A Challenge to the Food Industry. Trends in Food Science \& Technology, 5, 213-218. https://doi.org/10.1016/0924-2244(94)90251-8

[36] Barnett, S. (1973) Freezing of Coffee Extract to Produce a Dark Colored Freeze-Dried Product. AIChE Symposium Series, 69, 26-32. 